\title{
PERSEPSI SISWA TERHADAP PROGRAM SEKOLAH AMAN BENCANA (SAB) DALAM UPAYA MENINGKATKAN KESIAPSIAGAAN MENGHADAPI BENCANA DI SMP N 2 TABANAN TAHUN 2016
}

\author{
Ni Luh Arni Widyaningsih, Ni Komang Ekawati* \\ Program Studi Kesehatan Masyarakat Fakultas Kedokteran Universitas Udayana \\ *Email:niko_ekapsi@yahoo.co.id
}

\begin{abstract}
ABSTRAK
Indonesia merupakan negara yang sangat rawan akan kejadian bencana. Data Bank Dunia tahun 2010 juga menyebutkan Indonesia memiliki jumlah sekolah yang terletak pada daerah rawan bencana terbanyak keempat di dunia. Oleh karena itu, pemerintah melalui Badan Nasional Penanggulangan Bencana kemudian berkoordinasi dengan Badan Penanggulangan Bencana Daerah melakukan suatu program yang memiliki tujuan meningkatkan kesiapsiagaan bencana dari komunitas sekolah yang disebut program Sekolah Aman Bencana (SAB). Kesiapsiagaan merupakan salah satu bagian dari proses manajemen bencana yang memiliki elemen penting dalam pengendalin resiko bencana. Tujuan dari penelitian ini adalah untuk Untuk mengetahui gambaran persepsi siswa terhadap program Sekolah Aman Bencana di SMPN 2 Tabanan. Penelitian ini menggunakan desain penelitian deskriptif kualitatif dengan rancangan fenomenologi. Penelitian ini dilakukan di SMPN 2 Tabanan yang berlokasi di Kediri, Tabanan. Metode pengambilan data dalam penelitian ini menggunakan metode FGD (focus group discussion) dan wawancana mendalam. Peserta dalam FGD ini adalah siswa dan siswi SMP 2 Tabanan yang di kelompokkan berdasarkan jenis kelamin dan yang menjadi informan dalam wawancara mendalam adalah guru sekolah dan pemegang program SAB di BPBD Provinsi Bali. Hasil penelitian adalah siswa memiliki pengetahuan yang baik mengenai pengetahuan tentang program Sekolah Aman Bencana, siswa juga memiliki persepsi yang baik terhadap program Sekolah Aman Bencana dan siswa memiliki sikap yang positif atau mendukung adanya program Sekolah Aman Bencana
\end{abstract}

Kata Kunci: SMP, persepsi, Sekolah Aman Bencana (SAB)

\section{ABSTRACT}

Indonesia is a country that is very vulnerable to disasters. World Bank data in 2010 also states that Indonesia has a number of schools located in the fourth largest disaster prone area in the world. Therefore, the government through the National Disaster Management Agency then coordinated with the Regional Disaster Management Agency to carry out a program that had the objective of increasing disaster preparedness from the school community called the Disaster Safe School program (SAB). Preparedness is one part of the disaster management process that has an important element in controlling disaster risk. The purpose of this study is to find out an overview of students' perceptions of the Disaster Safe School program at Tabanan 2 Junior High School. This study uses a qualitative descriptive research design with phenomenological design. This research was conducted at Tabanan 2 Junior High School, located in Kediri, Tabanan. The method of data collection in this study used the FGD (focus group discussion) method and in-depth interviews. Participants in this FGD were students and students of Tabanan 2 Junior High School grouped by sex and who became informants in in-depth interviews were school teachers and SAB program holders at BPBD Bali Province. The results of the study were that students had good knowledge of knowledge about the Safe Disaster School program, students also had a good perception of the Safe Disaster School program and students had a positive attitude or supported the existence of a Disaster Safe School program

Keywords: Middle School, perception, Disaster Safe School (SAB) 


\section{PENDAHULUAN}

Telah lama diakui bahwa Negara Indonesia memiliki posisi yang sangat strategis secara geografis dimana letaknya berada diantara Australia dan benua Asia serta diantara dua samudra yaitu Samudra Pasifik dan Samudra Hindia. Di sisi lain, Indonesia juga terletak pada pertemuan 3 lempeng tektonik di dunia yaitu Lempeng Australia di selatan, Lempeng Euro-Asia di bagian barat dan Lempeng Samudra Pasifik di bagian timur wilayah Indonesia. Berdasarkan hal tersebut maka wilayah Indonesia rawan terhadap bencana banjir, tanah longsor, gunung meletus dan badai angin (Setiawan, 2010). Berdasarkan posisinya tersebut, maka hampir di seluruh Indonesia, termasuk Bali, berpotensi untuk mengalami kejadian bencana dan akan sangat mungkin terjadi setiap saat serta sangat sukar diperkirakan kapan dan dimana persisnya bencana tersebut akan terjadi

Sulitnya memprediksi dimana dan kapan bencana itu terjadi, maka sangat penting untuk membekali setiap orang dengan kesiapsiagaan bencana, terutama anak-anak. Data Bank Dunia tahun 2013 menyebutkan bahwa $28 \%$ penduduk Indonesia adalah anak-anak. Komunitas anak terbesar ada di sekolah. Menurut data Bank Dunia tahun 2010 menyebutkan Indonesia memiliki jumlah sekolah yang terletak pada daerah rawan bencana terbanyak keempat di dunia. Suatu penelitian kajian risiko bencana gempabumi pada SMP di wilayah Kabupaten Bantul Yogyakarta juga meyebutkan bahwa semua SMP di seluruh kecamatan di Kabupaten Bantul rawan terhadap risiko bencana alam gempabumi. Namun kesiapsiagaan komunitas SMP agar terhindar dari dampak bencana alam gempabumi masih rendah (Dwisiwi, dkk, 2012).

Kesiapsiagaan merupakan salah satu bagian dari proses manajemen bencana khususnya tahap pra-bencana. Pentingnya kesiapsiagaan merupakan salah satu elemen penting dari kegiatan pengendalian risiko bencana yang bersifat pro-aktif sebelum terjadi bencana (LIPI-UNESCO/ISDR, 2006 dalam Teguh, 2015). Untuk meningkatkan keterampilan dalam melakukan kesiapsiagaan maka Badan Penanggulangan Bencana Daerah Provinsi Bali sendiri telah melaksanakan program pembentukan Sekolah Aman Bencana (SAB). Program ini dibentuk pada tahun 2015 yang pelaksanaanya telah di dua sekolah yakni SMPN 2 Tabanan dan SMPN 3 Bangli. Oleh karena itu, peneliti tertarik untuk mengetahui persepsi siswa terhadap program Sekolah Aman Bencana yang dilakukan oleh BPBD Provinsi Bali di SMPN 2 Tabanan.

\section{METODE PENELITIAN}

Metode dari penelitian yang dilakukan berupa penelitian deskriptif kualitatif dengan rancangan fenomenologi. Teknik pengambilan sampel yang digunakan dalam penelitian ini adalah purposive sampling. Peneliti berperan sebagai peneliti utama yang berperan untuk melakukan pengambilan data.

Metode pengambilan data yang digunakan dalam penelitian ini yaitu focus group disscusion (FGD) dan wawancara mendalam. FGD kelompok pertama dengan peserta siswa perempuan (P1) dilakukan pada hari 
jumat tanggal 1 April 2016 di Ruang Laboratorium SMPN 2 Tabanan. Kemudian FGD kedua dengan peserta siswa laki-laki (L1) dilaksanakan hari sabtu tanggal 2 April 2016 di Perpustakaan SMPN 2 Tabanan. Selanjutnya FGD ketiga dan FGD keempat dilaksanakan pada hari yang sama yaitu sabtu, 9 April 2016 dengan kelompok peserta siswa perempuan (P2) terlebih dahulu dan dilanjutkan dengan kelompok peserta siswa laki-laki (L2). Wawancara terhadap salah satu guru SMPN 2 Tabanan dilaksanakan pada hari sabtu tanggal 30 April 2016. Kemudian untuk wawancara mendalam terhadap pemegang program Sekolah Aman Bencana, yang dalam hal ini Kepala Bidang I BPBD Provinsi Bali dilaksanakan pada hari jumat 20 Mei 2016. Triangulasi dari data penelitian dilakukan dengan triangulasi sumber dan metode, peer debriefing dan studi literatur.

\section{HASIL}

Informan dalam penelitian ini adalah siswa-siswi SMPN 2 Tabanan yang ikut terlibat dalam Program Sekolah Aman Bencana yang dilaksanakan di SMPN 2 Tabanan pada bulan September 2015. Jumlah informan dalam penelitian ini sebanyak 24 anak yang terdiri dari 12 siswa perempuan dan 12 siswa laki-laki. Jumah tersebut kemudian dibagi menjadi empat kelompok FGD yang terdiri dari dua kelompok siswa perempuan dan dua siswa laki-laki, tiap kelompok terdiri dari enam siswa. Hasil penelitian dibagi menjadi empat bagian yaitu gambaran karakteristikinforman, pengetahuan, persepsi serta sikap terkait program SAB.

\section{Pengetahuan Siswa Terhadap Program SAB}

Adapun yang termasuk dalam pengetahuan terkait program $S A B$ meliputi gambaran mengenai program $\mathrm{SAB}$ dan kerangka kerja SAB (non-struktural dan struktural). Gambaran program SAB dalam penelitian ini terdiri atas pengertian, bentuk kegiatan di dalamnya, materi yang disampaikan serta penyaji dari materi. Berdasarkan hasil FGD yang telah dilakukan pada siswa-siswi SMPN 2 Tabanan, beberapa informan memiliki jawaban pengertian $\mathrm{SAB}$ yang menyebutkan unsur "menanggulangi bencana" dan atau "kesigapan menghadapi bencana" dari pihak sekolah beserta warga sekolah.

“..Menurut pendapat saya, sekolah aman bencana adalah sekolah yang mampu mengatasi bencana alam contohnya gempa, kebakaran, gempa itu dulu dan memberitahu siswa-siswinya untuk mempersiapkan daerah aman bencana, contohnya dengan memasang jalur evakuasi-jalur evakuasi, daerah titik aman untuk berkumpul dan memasang denah-denah sekolah.." (L2d)

Kemudian untuk kegiatan apa saja yang ada dalam program SAB, jawaban dari informan yang telah peneliti rangkum meliputi kegiatan pemberian materi, simulasi, pembuatan jalur evakuasi serta pemasangan tanda arah evakuasi. Materi yang disampaikan dalam program SAB berupa jenis bencana serta penanggulangannya, sedangkan untuk penyaji materi dalam program $S A B$ sebagian besar informan dapat menjawab dengan tepat. Adapun pemberi materi yang disebutkan antara lain pihak Badan Penanggulangan Bencana Daerah (BPBD), Palang Merah Indonesia (PMI) dan Badan 
Meteorologi, Klimatologi dan Geofisika (BMKG)

Kerangka Kerja SAB terdiri atas dua bagian yaitu Kerangka Kerja Struktural yang mewakili unsur fisik dan Kerangka Kerja Non-Struktural yang merupakan unsur nonfisik SAB seperti pengetahuan dan kebijakan sekolah. Kerangka Kerja Struktural yang dibahas dalam penelitian ini meliputi tanda arah evakuasi dan titik aman berkumpul. Pengetahuan mengenai tanda arah evakuasi maupun titik aman berkumpul sebagian besar disampaikan dalam bentuk uraian fungsi dari kedua tanda tersebut. Selain itu, baik tanda arah evakuasi dan titik aman berkumpul saling berkaitan satu sama lain.

Sedangkan untuk Kerangka Kerja Non-Struktural yang dibahas yaitu pengetahuan siswa tentang materi kebencanaan yang dalam hal ini penanggulangan saat terjadi bencana gempa bumi dan kebakaran. Dari hasil pengumpulan data, sebagian besar informan telah mengetahui cara-cara penanggulangan tau apa yang harus dilakukan saat terjadi bencana baik gempa bumi atau kebakaran. Untuk bencana gempa bumi, para informan sebagaian besar menjawab "jangan panik" sebagai unsur yang sangat penting. Setelah itu diikuti dengan jawaban seperti "melindungi kepala saat melakukan evakuasi", "berlindung di bawah meja yang kuat" dan "segera menuju lapangan luas yang terhindar dari reruntuhan. Untuk penanggulangan bencana kebakaran terdapat kemiripan dengan penanggulangan bencana gempa bumi yaitu hal pertama yang harus dilakukan adalah "usahakan untuk tidak panik". Beberapa informan juga menyebutkan langkah-langkah lain yang diambil seperti usaha memadamkan api dengan menggunakan alat pemadam dan handuk basah.

\section{Persepsi Siswa Terhadap Program SAB}

Adapun yang dimaksud dengan persepsi siswa terhadap program SAB adalah pandangan siswa terkait program $\mathrm{SAB}$ yang ada di sekolahnya. Pandangan tersebut meliputi pandangan terhadap program secara umum, pelaksanaan program serta pandangan terhadap tanda arah evakuasi dan titik aman berkumpul.

Pandangan para informan terhadap program $\mathrm{SAB}$ tergolong sangat baik. Responden memandang bahwa program SAB merupakan kegiatan yang positif, kegiatan yang sangat baik bagi siswa-siswi di sekolah dan kegiatan yang diperlukan di setiap sekolah. Sebagaimana disebutkan dalam kuotasi berikut:

“...Kayak gimana ya, menurut saya kegiatannya sih lumayan positif untuk kegiatan sekolah. Untuk dalam segi...dalam segi lingkup sekolah sih udah lumayan bagus. Karena dapat memberi pengetahuan dalam kesigapan dalam menanggapi bencana..." (L1c)

Pelaksanaan program yang dibahas dalam penelitian ini meliputi proses pemberian materi dan proses saat sesi simulasi. Jadi untuk pandangan terhadap pelaksanaan program SAB mencakup pemahaman dan cara penyampaian materi, serta lancaranya dan kejelasan arahan saat simulasi. Berdasarkan hasil penelitian terkait pemberian materi, beberapa informan menyebutkan bahwa materi dapat dipahami karena suasana pemberian materi menyenangkan dan tidak tegang. Sedangkan 
untuk proses pelaksanaan simulasi juga cenderung lancar dan dapat dipahami. Seperti saat pemberian materi, karena situasinya menyenangkan dan peserta lebih tertarik saat melakukan praktek langsung

Pandangan mengenai tanda arah evakuasi dan titik aman berkumpul jika dilihat berdasarkan bentuk fisik tanda tersebut beberapa informan menyebutkan tanda sudah terlihat jelas dan membantu untuk evakuasi saat terjadi bencana. Sebagian informan ada yang menyebutkan bahwa tanda arah evakuasi memiliki ukuran yang kurang besar.

Untuk tanda titik aman berkumpul sudah memiliki ukuran yang sesuai dan jelas. Meskipun dari segi tandanya sudah jelas, beberapa informan juga ada yang menyebutkan bahwa area dari titik aman berkumpul atau penempatan dari tandanya belum sesuai karena belum sepenuhnya aman dari ancaman bahaya reruntuhan jika seandanya terjadi gempa bumi.

\section{Sikap Siswa Terhadap Program SAB}

Sikap tekait program SAB berupa pendapat setuju atau tidak siswa terhadap hal-hal terkait program SAB, apakah program tersebut dirasa penting atau tidak dan apa program perlu dilanjutkan atau tidak. Secara besar informan memiliki sikap yang baik terhadap program SAB.

Terhadap pernyataan "Program SAB merupakan Program Yang Sulit Dilaksanakan" sebagian besar informan menyatakan sikap tidak setuju. Berikut salah satu dari jawaban informan yang menyatakan tidak setuju : “...kalo saya sih gak setuju kak, soalnya kayak yang dibilang-bilang tu kan programnya bagus kegiatannya bisa bikin kita tau bencana, tau bahayanya trus tau..tau juga gimana atau harus ngapain..ee apatu ya penanggulangannya itu lah kak. Jadi enggak sulit karena kalo dipelajari itu gak sulit. Soalnya itu penting juga programnya.." (P2b). Berdasarkan kuotasi diatas maka dapat diketahui bahwa siswa memiliki sikap mendukung terhadap keberdaan program SAB karena merasa mendapat manfaat dari program ini. Oleh karena itu siswa juga menyebutkan bahwa program tidak sulit untuk dilaksanakan disamping program SAB ini dianggap penting.

Selanjutnya untuk pernyataan kedua yaitu "Program SAB Tidak Perlu Diterapkan Lagi Di Sekolah" memiliki hubungan dengan pernyataan pertama karena berkaitan dengan sikap atas keberlanjutan program. Dari beberapa informan, keberlanjutan dari program dianggap perlu karena program dapat memberikan manfaat yang besar untuk melindungi siswa agar tidak menjadi korban saat terjadi bencana.

Kemudian untuk pernyataan ketiga yang menyebutkan bahwa "Hanya peran guru yang penting dalam upaya pembentukan SAB" dimaksudkan untuk mengetahui sikap informan terhadap peranperan yang ada dalam program SAB. Seluruh informan dalam penelitian ini menyatakan bahwa tidak setuju terhadap pernyataan "Hanya peran guru yang penting dalam upaya pembentukan $\mathrm{SAB}^{\prime \prime}$.

Sebagian besar informan menyebutkan bahwa keterbatasan guru 
untuk mengarahkan atau melindungi siswanya sebagai alasan mengapa bukan hanya peran guru saja yang penting dalam program Sekolah Aman Bencana. Diperlukan peran dari elemen sekolah yang lain termasuk siswa di sekolah. Hal tersebut disampaikan dalam kuotasi informan sebagai berikut:

“Saya tidak setuju karena guru tidak selalu ada mengawasi murid-muridnya tau siswasiswinya yang berada di sekolah dan peran..peran murid juga-juga sangat penting untuk pembentukan sekolah aman bencana. Sekian dan terimakasih." (L2e)

\section{DISKUSI}

\section{Pengetahuan Siswa Terhadap Program SAB}

Berdasarkan hasil yang didapat dari penelitian ini maka dapat diketahui gambaran pengetahuan siswa tentang program SAB tergolong cukup baik. Adapun yang termasuk pengetahuan tentang program Sekolah Aman Bencana meliputi gambaran terkait program SAB dan kerangka kerja program SAB.

Untuk pengetahuan dari gambaran program SAB tergolong baik. Jawaban dari sebagian besar informan terkait pengertian program $\mathrm{SAB}$ mengarah pada kegiatankegiatan yang dalam program $\mathrm{SAB}$ yang diterapkan di SMPN 2 Tabanan. Hasil penelitian terhadap pengetahuan siswa tentang gambaran kegiatan, materi yang diberikan serta siapa saja penyaji materi menunjukkan hasil yang baik. Dimana sebagian besar informan bisa menyebutkan salah satu atau beberapa kegiatan, materi serta pemateri dalam program SAB di SMPN 2 Tabanan.
Selanjutnya untuk pengetahuan informan terkait kerangka kerja program SAB baik kerangka kerja struktural maupun kerangka kerja non struktural tergolong baik. Kerangka kerja struktural merupakan kerangka kerja yang terkait konstruksi fisik SAB yang dalam hal ini dibahas mengenai tanda arah evakuasi dan titik aman berkumpul. Sebagian besar informan mengetahui apa itu tanda arah evakuasi dan titik aman berkumpul berdasarkan fungsi dari kedua tanda tersebut. Pernyataan tersebut sesuai Modul Materi Sekolah Aman Bencana 2015 dari BPBD Provinsi Bali yang menyatakan bahwa tanda arah evakuasi adalah penanda yang mengarahkan jalur evakuasi menuju tempat evakuasi yang aman. Sedangkan untuk titik aman berkumpul disebutkan bahwa sebagai penanda untuk daerah yang aman dari ancaman bencana khususnya gempa maupun kebakaran. Untuk selanjutnya terkait dengan pengetahuan informan terhadap kerangka kerja non struktural tergolong baik. Kerangka kerja non struktural yang ada dalam penelitian ini berupa pengetahuan tentang penanggulangan bencana gempa bumi dan kebakaran Dalam menghadapi atau melakukan penanggulangan terhadap bencana gempa bumi, sebagian besar informan menyebutkan hal-hal yang harus dilakukan berupa menghindari kepanikan, berlindung di bawah meja yang kuat jika berada di dalam ruangan dan segera menuju lapangan terbuka yang jauh dari gedung-gedung untuk menghindari reruntuhan bangunan. Selain itu pada saat melakukan evakuasi juga diharapkan melindungi diri dengan meletakkan tas di atas kepala. Hal tersebut sesuai dengan apa yang disampaikan dalam 
Buku Saku Penanggulangan Bencana BNPB tahun 2012 dan pernyataan dari pihak pemegang program SAB BPBD Provinsi Bali.

Menurut penelitian yang dilakukan Dien (2015) disebutkan bahwa penyuluhan kesehatan memiliki pengaruh terhadap kesiapsiagaan menghadapi bencana gempa bumi pada siswa SMP Kristen Kakaskasen Kota Tomohon. Jika dibandingkan dengan pengetahuan siswa SMPN 2 Tabanan terhadap kesiapsiagaan bencana gempa bumi maka pemberian materi dalam bentuk penyuluhan di program Sekolah Aman Bencana memiliki pengaruh pada kesiapsiagaan sisiwa menghadapi bencana gempa bumi. Kemudian dengan adanya praktek langsung dalam bentuk simulasi juga mempengaruhi kesiapsiagaan siswa SMPN 2 Tabanan dalam menghadapi bencana gempa bumi. Hal itu sejalan dengan penelitian yang dilakukan oleh Afandi (2014) yang menyebutkan bahwa pelatihan simulasi efektif meningkatkan pengetahuan siswa tentang mitigasi bencana gempa bumi di SMA Muhammadiyah 1 Surakarta.

Untuk penanggulangan saat terjadi bencana kebakaran, informan menyebutkan hal-hal yang harus dilakukan seperti menghindari kepanikan, menyelamatkan dokumen atau barang berharga, berusaha segera memadamkan api dengan alat pemadam ringan atau lap yang dibasahi air. Setelah berhasil menyelamatkan diri keluar dari tempat kebakaran segera menghubungi bantuan dari petugas pemadam kebakaran, ambulans maupun PLN. Hal tersebut sesuai dengan materi penanggulangan bencana kebakaran yang terdapat terdapat dalam
Modul Materi SAB 2015 (BPBD Provinsi Bali, 2015).

\section{Persepsi Siswa Terhadap Program SAB.}

Berdasarkan hasil penelitian yang didapat, sebagian besar informan memiliki pandangan yang positif terhadap program Sekolah Aman Bencana. Adapun aspek persepsi terhadap program SAB yang dilihat antara lain pandangan terhadap program secara umum, pelaksanaan program dan pandangan terhadap tanda arah evakuasi maupun titik aman berkumpul yang ada di SMPN 2 Tabanan.

Pandangan informan terhadap program SAB secara umum termasuk pandangan yang baik. Hal itu karena berdasarkan hasil penelitian yang didapat, sebagian besar informan baik laki-laki maupun perempuan memandang program SAB memberikan manfaat pada para siswa dan sekolah.

Selanjutnya, dalam aspek pelaksanaan program $\mathrm{SAB}$, informan dari penelitian tergolong memiliki pandangan yang baik terhadap pelaksanaan program SAB. Kemudian untuk aspek persepsi program SAB terkait tanda arah evakuasi dan titik aman berkumpul, sebagian besar informan memiliki pandangan yang cukup baik. Pandangan yang baik terhadap keberadaan Program SAB sangat baik bagi pelaksanaan dan keberlanjutan program dimana menurut Teori Helath Belief Model (Sarwono, 2012), suatu program atau intervensi perubahan perilaku yang diharapkan akan semakin cepat tercapai apabila sasaran dari intervensi merasa ada manfaat yang diterima dari program. 


\section{Sikap Siswa Terhadap Program SAB}

Jika disimpulkan, secara umum sebagian besar informan memiliki sikap yan positif terhadap program Sekolah Aman Bencana, baik itu terkait kemudahan dari pelaksanann, keberlanjutan program dan keterlibatan berbagai peran di dalam program. Dengan sikap yang positif tersebut maka perilaku kesiapsiagaan menghadapi bencana dapat diwujudkan oleh siswa SMPN 2 Tabanan. Hal tersebut sesuai dengan Teori Proses Perubahan Sikap dari Kelman tahun 1958 yang menyebutkan bahwa perubahan perilaku individu akan menjadi optimal apabila telah mencapai proses internalisasi yang merupakan suatu keadaan dimana perilaku yang baru dianggap positif bagi diri individu sendiri dan diintegrasikan dengan nilai-nilai lain dalam hidupnya (Sarwono, 2012).

\section{SIMPULAN}

Pengetahuan siswa SMPN 2 Tabanan terhadap program SAB tergolong baik. Para siswa mampu menyampaikan hal-hal terkait program Sekolah Aman Bencana sesuai dengan apa yang disampaikan oleh pemegang program Sekolah Aman Bencana di BPBD Provinsi Bali. Sebagian besar siswa SMPN 2 Tabanan juga memiliki persepsi yang baik terhadap program SAB. Kemudian untuk sikap terkait program $S A B$, sebagian besar siswa SMPN 2 Tabanan memiliki sikap yang positif.

\section{DAFTAR PUSTAKA}

Afandi R. 2014. Pengaruh Pelatihan Simulasi Terhadap Pengetahuan Siswa Kelas X IPS Tentang Mitigasi Bencana Gempa Bumi di SMA Muhammadiyah 1 Surakarta.
Skripsi. Universitas Muhammadiyah Surakarta

Astuti, A. P., \& Yuliyanto, E. 2015. “I Am A Survivor" Bervisi SETS Upaya Menciptakan Komunitas Sadar Bencana Di Sekolah. Jurnal Pendidikan Sains, 03(02), 35-41.

BPBD Provinsi Bali. 2015. Modul Materi

Sekolah Aman Bencana 2015. Denpasar.

BNPB. 2012. Buku Saku Tanggap Tangkas Tangguh Menghadapi Bencana. Jakarta: BNPB.

BNPB. 2012. Peraturan Kepala Badan Nasional Penanggulangan Bencana Nomor 4 Tentang Sekolah/Madrasah Aman Dari Bencana. Jakarta: BNPB.

Dien, R. J., \& Malara, R. T. 2015. Pengaruh Penyuluhan Kesehatan Terhadap Kesiapsiagaan Menghadapi Bencana Gempa Bumi Pada Siswa SMP Kristen Kakaskasen Kota Tomohon. E-Journal Keperawatan (e-Kp), 3(2), 1-7

Dwisiwi, R., Surachman; Sudomo, J., \& Wiyatno, Y. (2012). Pengembangan Teknik Mitigasi Dan Manajemen Bencana Alam Gempabumi Bagi Komunitas SMP Di Kabupaten Bantul Yogyakarta. Dalam : Seminar Nasional Penelitian, Pendidikan dan Penerapan MIPA (p. F-1-F-10). Yogyakarta: Universitas Negeri Yogyakarta.

Hamdani, Ahmad A. 2015. Kesiapsiagaan Terhadap Bencana Gempa Bumi Berdasarkan Status Kesiagaan Sekolah Di SMP N 1 dan SMPN 2 Imogiri Bantul Yogyakarta. Skripsi. Sekolah Tinggi Ilmu Kesehatan 'Aisyiyah Yogyakarta. Honesti, L., \& Djali, N. (2012). Pendidikan Kebencanaan Di Sekolah - Sekolah Di 
Arc. Com. Health • Juni 2017

ISSN: 2527-3620

Indonesia Berdasarkan Beberapa Sudut

Pandang Disiplin Ilmu Pengetahuan.

Jurnal Momentum, 12(1), 51-56.

LIPI-UNESCO/ISDR. (2006).Kajian

Kesiapsiagaan Masyarakat Dalam

Mengantisipasi Bencana Gempa Bumi

dan Tsunami. Jakarta

Sarwono, S. (2012). Sosiologi Kesehatan :

Beberapa Konsep serta Aplikasinya ( $5^{\text {th }}$ ed). Yogyakarta : Gadjah Mada University Press. 